\section{ACUTE PERFORATED PEPTIC ULCER} A STUDY OF THE RECENT FALL IN MORTALITY BY

\section{F. AVERY JONES,* M.D., F.R.C.P.}

\section{P. J. PARSONS, M.D., M.R.C.P.}

AND

BARBARA WHITE, B.SC.

(From the Gastro-enterological Department, Central Middlesex Hospital)

This paper records a study of 490 consecutive cases of acute perforation of peptic ulcer treated in this hospital from 1938 to 1948 inclusive, and discusses the factors which may have contributed to the considerable fall in mortality during that time.

Recent papers provide evidence that the mortality from acute perforation has declined from the high levels which prevailed before the war. DeBakey (1940) reviewed the literature published between 1930 and 1940 , and his collected series of cases showed a total mortality of $25.2 \%$ in 16,752 cases and an operative mortality of $23.4 \%$ in 15,340 cases. Published series that allow a comparative analysis of the mortality in recent years show a uniform decrease in Great Britain, America, and Scandinavia (Table I).

TABLE I.-Comparative Degrees of Mortality from Perforated Peptic Ulcer

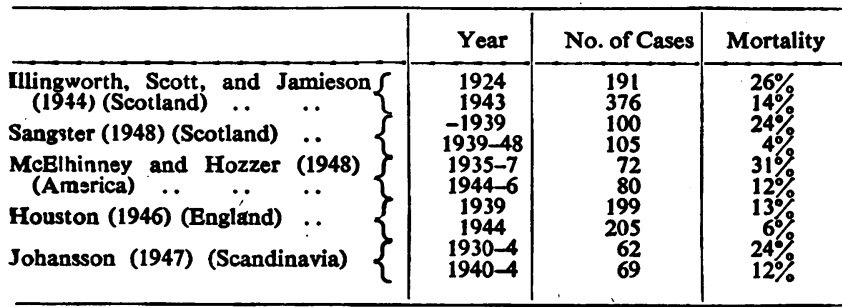

In addition, recent publications provide a number of series with low mortalities. Baritell (1947) had only three deaths among 90 admissions, and two of these occurred in patients who were not operated on. McClure (1940) had a mortality of $7.7 \%$ among 91 cases, and Graham and Tovee (1945) recorded $8.8 \%$ among 114 admissions, with only $6.3 \%$ in the operated group.

These figures provide evidence of a trend, but further analyses are needed, because there are many factors which affect the interpretation of fatality rates. The age distribution of the groups, the time interval between perforation and operation, the comparison of personal series with mass hospital figures, and the natural bias in favour of publishing successful rather than unsuccessful series provide some of the statistical pitfalls in comparing groups. To obtain the clearest assessment of the factors responsible for a fall in mortality it is desirable to study the problem in one unit over a number of years.

\section{Present Investigation}

Our series-consisting of 455 patients with frank acute perforation who received surgical treatment and 35 patients who for various reasons were not operated on-was treated between 1938 and 1948. During this period there were

*In receipt of an expenses grant from the Medical Research Council. also 20 non-fatal admissions for "leaking ulcer." These last are patients on whom operation was not performed because it was felt that the perforation had sealed off : in many of them the diagnosis was not firmly established and the group has been excluded, as is usually done in other published series of acute perforation.

Ulcers clearly within the pyloric antrum have been classified as gastric, but the juxtapyloric ulcers have been included in the duodenal group, as recommended by Illingworth, Scott, and Jamieson (1944). Cases subsequently found to be carcinomatous have been inc'uded if their initial operative diagnosis was simple gastric ulcer ; these are the subject of a paper by Dr. R. Doll at page 215 of this issue.

In this series the greatest care has been taken to ensure the inclusion of all patients, not omitting those who died soon after admission and those whose perforation had been diagnosed only at necropsy.

The age and site distribution is shown in Table II. Comparison with other series reveals important differences,

Table II.-Series 1938-48. Age and Site Distribution

\begin{tabular}{|c|c|c|c|c|c|c|c|c|c|c|}
\hline \multirow{2}{*}{$\begin{array}{c}\text { Age } \\
\text { (Years) }\end{array}$} & \multirow{2}{*}{ Total } & \multirow{2}{*}{ Deaths } & \multicolumn{2}{|c|}{ G.U. } & \multicolumn{2}{|c|}{ D.U. } & \multicolumn{2}{|c|}{ J.U. } & \multicolumn{2}{|c|}{$?$} \\
\hline & & & $\mathbf{M}$ & $\mathbf{F}$ & $\mathbf{M}$ & $\mathbf{F}$ & $\mathbf{M}$ & $\mathbf{F}$ & $\mathbf{M}$ & $\mathbf{F}$ \\
\hline $\begin{array}{l}15- \\
20= \\
25= \\
30= \\
35= \\
40= \\
45= \\
50= \\
55= \\
60= \\
65= \\
70= \\
75= \\
80= \\
85+\end{array}$ & $\begin{array}{r}3 \\
14 \\
34 \\
47 \\
53 \\
62 \\
57 \\
50 \\
59 \\
44 \\
34 \\
18 \\
10 \\
3 \\
2\end{array}$ & $\begin{array}{r}- \\
2 \\
4 \\
3 \\
4 \\
10 \\
10 \\
15 \\
17 \\
9 \\
11 \\
7 \\
2 \\
2\end{array}$ & \begin{tabular}{rr}
3 & \\
3 & \\
2 & \\
11 & $(2)$ \\
4 & $(1)$ \\
10 & $(1)$ \\
13 & $(7)$ \\
4 & $(2)$ \\
14 & $(5)$ \\
18 & $(7)$ \\
6 & $(1)$ \\
7 & $(3)$ \\
2 & $(2)$ \\
2 & $(1)$ \\
\multicolumn{2}{c}{-}
\end{tabular} & $\begin{array}{l}- \\
1 \\
2 \\
1 \\
- \\
2 \text { (1) } \\
1 \text { ( } \\
4(3) \\
3(1) \\
2(1) \\
2(2) \\
1 \text { (1) } \\
-\end{array}$ & $\begin{array}{rr}3 & \\
9 & \\
30 & (2) \\
32 & (2) \\
43 & (2) \\
47 & (1) \\
39 & (2) \\
42 & (7) \\
39 & (9) \\
22 & (7) \\
21 & (4) \\
7 & (6) \\
5 & (3) \\
2 & (2)\end{array}$ & $\begin{array}{l}- \\
1 \\
2 \\
1 \\
2 \\
4(1) \\
3(1) \\
1 \\
3(1) \\
3(2) \\
2(1) \\
1 \\
=\end{array}$ & $\begin{array}{l}= \\
\overline{1} \\
3 \\
\overline{1} \\
2 \\
= \\
= \\
=\end{array}$ & $\begin{array}{l}= \\
= \\
\bar{z} \\
= \\
= \\
= \\
= \\
=\end{array}$ & $\begin{array}{l}= \\
= \\
= \\
= \\
\bar{z} \\
= \\
=\end{array}$ & $\begin{array}{l}\bar{z} \\
\bar{z} \\
\bar{z} \\
\bar{z} \\
\bar{z} \\
=\end{array}$ \\
\hline Total & 490 & 96 & $96(32)$ & $21(9)$ & 341 (47) & $23(6)$ & 7 & $1(1)$ & $1(1)$ & - \\
\hline
\end{tabular}

$\mathbf{M}: \mathbf{F}=9.9: 1$. D.U.: G.U. $=3 \cdot 1: 1$. The numbers of deaths, are shown in parentheses.

which are being studied further. We are here concerned with the change in mortality that has occurred during the period 1938 to 1948 inclusive. The mortality has fallen very appreciably during that 11 -year period (Table III).

TABLE III.-Mortality in the Series

\begin{tabular}{l|c|c|c|c|c|c|c|c|c|c|c}
\hline & 1938 & 1939 & 1940 & 1941 & 1942 & 1943 & 1944 & 1945 & 1946 & 1947 & 1948 \\
\hline Total cases & 39 & 36 & 32 & 40 & 35 & 47 & 48 & 45 & 53 & 58 & 57 \\
Total deaths & 12 & 9 & 7 & 9 & 13 & 6 & 10 & 9 & 10 & 8 & 3 \\
\hline $\begin{array}{l}\text { Unoperated cases } \\
\text { Number }\end{array}$ & - & 1 & - & 2 & 2 & 3 & 7 & 4 & 7 & 6 & 3 \\
$\begin{array}{l}\text { Deaths } \\
\text { Operated cases } \\
\text { Number } \\
\text { Deaths }\end{array}$ & 12 & -5 & 2 & 2 & 3 & 6 & 4 & 7 & 5 & 2 \\
12 & 85 & 32 & 38 & 33 & 44 & 41 & 41 & 46 & 52 & 54 \\
\hline
\end{tabular}

This would be expected if the population concerned had become younger, if the time interval between perforation and operation had been reduced, if the number of nonoperated late cases had declined, or if the technique of operation or aftercare had improved.

The improvement has been effected in spite of an older population being admitted, without an appreciable fall in the proportion of late cases, and notwithstanding the admission of a higher proportion of moribund cases in which the diagnosis was not established. It fo'lows that the improvement must be due to a better routine associated with operation and aftercare. To demonstrate these points the first three years have been compared with the last two 
TABLE IV.-Comparison of Early and Late Years of the Period

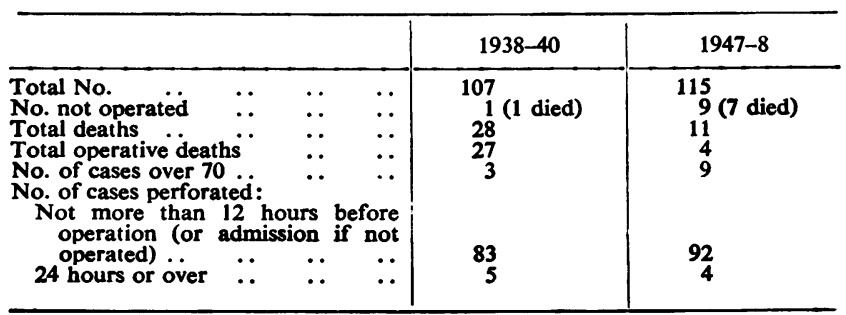

years (Table IV). These periods provide approximately equal total figures and represent two periods, before and after the introduction of antibiotics and of modern anaesthetic techniques.

The increase in the number of cases not operated on in the later years is mainly due to three factors. First, more unsuspected perforations have come to light because for all deaths in hospital within 24 hours of admission a coroner's post-mortem examination is now performed, whereas previously a death certificate might have been issued without a post-mortem examination, and this was most likely to happen with the elderly. For examp'e, the man aged 80 who was recently admitted with a six-months history of anginal pain and sudden onset of severe precordial and upper abdominal pain would probably have been certified as dying from coronary thrombosis and the unsuspected acute perforation would have remained unrecorded. Secondly, since 1940, necropsies have been performed on 64 out of 68 dying from bleeding peptic ulcer, and the diagnosis of associated perforation was confirmed in six of them. It is unlikely that as high a proportion were previously subjected to necropsy or that the same proportion is true for other hospitals. Thirdly, the proportion of admissions over 70 years of age has increased, and it is these elderly folk, often living alone without friends or relatives near by-so often the case in large cities-who come in moribund, having perforated often more than 24 hours previously, some indeed having been completely prostrated by the perforation and having been unable to attract assistance for long periods.

\section{Non-operated Cases}

During the period of this series there has been no change in surgical policy towards the late cases. The increase in non-operated cases is essentially due to the greater accuracy of diagnosis, to the insistence on post-mortem examinations, and to the much larger number of very elderly admissions; the matter, however, needs further consideration.

In the whole series there were 35 patients on whom no operation was performed; of these, 32 died. They fall into three categories.

In the first there were 13 patients who were admitted with gross peripheral circulatory failure ; all of them died within a few hours. Their history suggested that perforation had occurred at least 12 hours previously and mainly between 24 and 72 hours before admission. Eight of the 13 were over 65 ; the youngest was 58 .

The second group comprised nine patients for whom operation was not advised or (in one case) was refused by the pat:ent; three recovered. Three in this group were really suitable for operation, but it was decided to follow the technique of medical treatment advocated by Hermon Taylor (1946); two of the three died. The remaining six were treated medically because operation was refused or because of very serious associated medical conditionse.g., gangrene of leg, an extreme degree of emphysema, or senility.

In the third group (13 patients) the diagnosis of acute perforation was not made during life, although it may have been considered as a possibility. It is noteworthy that in six of these patients, aged $47,59,73,76,78$, and 79 years, there had been very severe gastro-duodenal bleeding and they were profoundly ill but showed none of the usual manifestations of acute perforation, although one was thought to have had a pulmonary embolism. In the other seven cases there was little to suggest the diagnosis. One was already moribund with Hodgkin's disease, two were unconscious on admission, and the others were in extremis - ? coronary infarction. One was admitted with á subphrenic abscess, shown at necropsy to be due to a perforated ulcer.

\section{Operated Cases}

The fall in mortality among the operated cases treated in hospital has been particularly impressive. Table IV shows that during $1938-40$ there were 106 cases, with 27 deaths. In 1947-8 there were the same number, with only four deaths.

The fall cannot be explained by a change in the age distribution of the population. There has been a slight increase in the number operated on within 12 hours of perforation (Table V), but not sufficient to contribute materially to the improved results. The improvement has been seen in all age groups (Table VI) and in both early and late cases, but has affected duodenal more than gastric ulcers (Table VII).

TABLE V.-Comparative Mortality by Delay Before Operation

\begin{tabular}{|c|c|c|c|c|c|}
\hline & & \multicolumn{2}{|c|}{$1938-40$} & \multicolumn{2}{|c|}{$1947-8$} \\
\hline & & No. & Deaths & No. & Deaths \\
\hline $\begin{array}{l}\text { Up to } 12 \text { hours } \\
\text { Over } 12 \text { ? " }\end{array}$ & $\because$. & $\begin{array}{r}83 \\
22 \\
1\end{array}$ & $\begin{array}{l}16(19 \cdot 3 \%) \\
11(50 \%)\end{array}$ & $\begin{array}{r}90 \\
14 \\
2\end{array}$ & $\begin{array}{c}4(4 \cdot 4 \%) \\
0 \\
-\end{array}$ \\
\hline
\end{tabular}

TABLE VI.-Comparative Mortality by Age

\begin{tabular}{|c|c|c|c|c|c|}
\hline \multirow{2}{*}{ Age } & & \multicolumn{2}{|c|}{$1938-40$} & \multicolumn{2}{|c|}{ 1947-8 } \\
\hline & & No. & Deaths & No. & Deaths \\
\hline $\begin{array}{l}\text { Up to } 35 \text { years } \\
35-69 \text { " } \\
70+\end{array}$ & $\ddot{x}$ & $\begin{array}{r}27 \\
76 \\
3\end{array}$ & $\begin{array}{r}4 \\
22 \\
1\end{array}$ & $\begin{array}{r}27 \\
75 \\
4\end{array}$ & $\begin{array}{l}0 \\
3 \\
1\end{array}$ \\
\hline
\end{tabular}

TABLE VII.-Comparative Mortality by Site

\begin{tabular}{lcc|c|c|c|c}
\hline & & & \multicolumn{2}{|c|}{$1938-40$} & \multicolumn{2}{c}{$1947-8$} \\
\cline { 3 - 6 } & & & No. & Deaths & No. & Deaths \\
\hline $\begin{array}{l}\text { Gastric } \\
\text { Duodenal }\end{array}$ & $\cdots$ & $\cdots$ & 23 & 7 & 24 & 2 \\
Jejunal & $\cdots$ & $\cdots$ & $\frac{83}{20}$ & - & $\frac{2}{2}$ & $\frac{-}{4}$ \\
\hline & Total & $\cdots$ & 106 & 27 & 106 & 4 \\
\hline
\end{tabular}

The improvement is refiected in the change in the causes of death and in the frequency of complications.

Before 1943 there was a high proportion of early deaths from post-operative shock or from general peritonitis, the patients dying within two days. Since 1943 there have been no early deaths, and the delayed deaths have been associated with haemorrhage, subphrenic abscess, or various miscellaneous complications. The change of character 


\begin{tabular}{|c|c|c|c|c|c|c|c|c|c|}
\hline \multirow{2}{*}{$\begin{array}{l}\text { TIME OF DEATH } \\
\text { POST OPERATIVE } \\
\text { DAY }\end{array}$} & \multicolumn{9}{|c|}{ GASTRIC ULCER } \\
\hline & 1938 & 1939 & 19401 & 19411 & 1942 & 194319 & 1944194 & $245^{\prime}|1946|$ & 19471948 \\
\hline IST & & 0 & 0 & $\mathrm{O}$ & 0 & & & & \\
\hline 2 ND & 0 & 0 & & & 0 & & & & \\
\hline 3 RD-7TH & & & & $\begin{array}{l}\mathbb{P}_{2} \\
\mathrm{O}_{2}\end{array}$ & & & & & \\
\hline $8 \mathrm{TH}-14 \mathrm{TH}$ & & & \begin{tabular}{|c|}
$\mathbf{s}$ \\
$\mathbf{s}$ \\
\end{tabular} & & $\mathbf{a}$ & & $\frac{\mathbb{8}}{\mathbb{E}_{3}}$ & 0 & \\
\hline LATER & & (5) & & Q & $\begin{array}{l}\text { (S) } \\
\text { (5) }\end{array}$ & & $\square$ & & ${ }^{\circledR}$ \\
\hline $\begin{array}{l}\text { KEY } \\
\text { HAEMATEMESIS } \\
\text { O POST-OPERATIV } \\
\text { OR PERITONITIS } \\
\text { (8) SUB-PHRENIC AE } \\
\text { (8) RESPIRATORY }\end{array}$ & $\begin{array}{l}\text { E SHC } \\
\text { BSCES }\end{array}$ & & & $\begin{array}{l}\text { INTE } \\
\text { CELL } \\
\text { CER } \\
\text { CEL } \\
\text { COR }\end{array}$ & $\begin{array}{l}\text { UND } \\
\text { STIIN } \\
\text { ANE } \\
\text { REBR } \\
\text { LLULI }\end{array}$ & $\begin{array}{l}\text { INFEC } \\
\text { IAL O } \\
\text { OUS } \\
\text { AL H H } \\
\text { Tis OF } \\
\text { RY TH }\end{array}$ & $\begin{array}{l}\text { CTION } \\
\text { OBSTR } \\
\text { AAEMOO } \\
\text { FABDO } \\
\text { HROME }\end{array}$ & $\begin{array}{l}\text { N } \\
\text { RUCTION } \\
\text { ORRHACE } \\
\text { OMINAL } \\
\text { BOSIS }\end{array}$ & WALL \\
\hline
\end{tabular}

CHART 1.-Acute perforations. Operated cases of gastric ulcer, 1938-48. Cause and time of death.

\begin{tabular}{|c|c|c|c|c|c|c|c|c|c|c|c|}
\hline \multirow{2}{*}{$\begin{array}{l}\text { TIME OF DEATH } \\
\text { POST-OPERATIVE } \\
\text { DAY }\end{array}$} & \multicolumn{11}{|c|}{ DUODENAL ULCER } \\
\hline & 1938 & 1939 & 194019 & 941 & 1942 & 1943 & & 1945 & 1946 & $\mid 1947$ & 1948 \\
\hline IST & 10 & 0 & O & & 0 & & & & & & \\
\hline 2 ND & 0 & 0 & & & 0 & & & & & & \\
\hline $3 R D-7 T H$ & 0 & $\boldsymbol{a}$ & 0 & $\begin{array}{l}0 \\
0 \\
0\end{array}$ & (1) & & 0 & 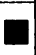 & 0 & a & \\
\hline $8 T H-14 T H$ & $(8)$ & 0 & & (5) & & (B) & & (1) & & & (1) \\
\hline LATER & (1) & (1) & (5) & & S & (5) & & $\begin{array}{l}\text { (5) } \\
\text { (5) }\end{array}$ & & & \\
\hline $\begin{array}{l}\frac{\text { KEY }}{7} \\
\text { HAEMATEMESI } \\
\text { HOST-OPERATII } \\
\text { OR PERITONIT } \\
\text { (5) SUB-PHRENIC A } \\
\text { (B) RESPIRATORY }\end{array}$ & $\begin{array}{l}\text { E SHO } \\
\text { SSCESS }\end{array}$ & & & & & & & & $\begin{array}{l}\text { ION } \\
\text { HACE } \\
\text { INAL }\end{array}$ & & \\
\hline
\end{tabular}

ChART 2-Acute perforations. Operated cases of duodenal ulcer, 1938-48. Cause and time of death.

during the past two years lung abscess and empyema have disappeared and the frequency of both subphrenic abscess and wound infection has fallen considerably. Possible factors contributing towards this fall in mortality include improved surgical technique, improved anaesthesia, the routine use of antibiotics, and better post-operative care.

TABLE VIII.-Complications

\begin{tabular}{|c|c|c|c|c|c|}
\hline & & \multirow{2}{*}{\multicolumn{2}{|c|}{$\frac{1938-40}{\begin{array}{r}106 \\
27\end{array}}$}} & \multirow{2}{*}{\multicolumn{2}{|c|}{$\begin{array}{c}1947-8 \\
106 \\
4\end{array}$}} \\
\hline $\begin{array}{l}\text { No. of admissions } \\
\text { Deaths } \ldots\end{array}$ & $\begin{array}{l}\cdots \\
\ldots\end{array}$ & & & & \\
\hline \multicolumn{2}{|c|}{ Complications } & No. & Deaths & No. & Deaths \\
\hline $\begin{array}{l}\text { Post-operative shock } \\
\text { tonitis ... } \\
\text { Chest: } \\
\text { Basal collapse, pne } \\
\text { bronchitis . } \\
\text { Lung abscess . } \\
\text { Empyema } . \\
\text { Subphrenic abscess } \\
\text { Wound infection } \\
\text { Haematemesis/melaena }\end{array}$ & 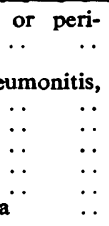 & $\begin{array}{r}40 \\
3 \\
2 \\
8 \\
36 \\
10\end{array}$ & $\begin{array}{l}7 \\
2 \\
2 \\
7 \\
6 \\
4\end{array}$ & $\begin{array}{r}44 \\
0 \\
0 \\
1 \\
10 \\
7\end{array}$ & $\begin{array}{l}2 \\
0 \\
0 \\
0 \\
2 \\
2\end{array}$ \\
\hline
\end{tabular}

The series has not been correlated with the seniority of the surgeons concerned, but this could offer no explanation of the improvement in recent years. During the pre-war and war years the cases were invariably operated on by a resident senior surgeon, but since the war many more have been operated on by surgical assistants.

During the period reviewed there have been important changes in anaesthetic technique, notably the introduction of cyclopropane and curare. In the earlier years most patients were anaesthetized with gas, oxygen, and ether, and a deep anaesthetic was necessary to overcome the rigidity of the abdominal muscles ; the use of cyclopropane allowed a much lower concentration of ether. The introduction of cyclopropane coincided with the increased use of sulphonamides, and curare and penicillin came into general use almost simultaneously.

TABle IX.-Acute Perforations. Operated Cases

\begin{tabular}{|c|c|c|c|c|c|c|c|c|c|c|c|}
\hline & 1938 & 1939 & 1940 & 1941 & 1942 & 1943 & 1944 & 1945 & 1946 & 1947 & \begin{tabular}{|l|l}
1948 \\
\end{tabular} \\
\hline \begin{tabular}{ll} 
Total No. & $\ldots$ \\
Deaths & \multicolumn{1}{c}{. } \\
Sulphonamides \\
Cyclopropane \\
Penicillin &. \\
Curare &.
\end{tabular} & $\begin{array}{l}39 \\
= \\
=\end{array}$ & $\begin{array}{r}35 \\
8 \\
2 \\
= \\
=\end{array}$ & $\begin{array}{r}32 \\
7 \\
6 \\
= \\
\end{array}$ & $\begin{array}{l}38 \\
7 \\
10 \\
= \\
=\end{array}$ & $\begin{array}{r}33 \\
11 \\
19 \\
6 \\
-\end{array}$ & $\begin{array}{r}44 \\
3 \\
41 \\
22 \\
\\
\end{array}$ & $\begin{array}{r}41 \\
4 \\
41 \\
35 \\
\\
\end{array}$ & $\begin{array}{r}41 \\
5 \\
38 \\
38 \\
5 \\
4\end{array}$ & $\begin{array}{r}46 \\
3 \\
42 \\
39 \\
8 \\
12\end{array}$ & $\begin{array}{l}52 \\
3 \\
50 \\
49 \\
47 \\
46\end{array}$ & $\begin{array}{l}54 \\
1 \\
52 \\
54 \\
54 \\
50\end{array}$ \\
\hline
\end{tabular}

Table IX shows the different factors which may have influenced the fall in mortality, and their time of introduction.

\section{Discussion}

These results clearly demonstrate a remarkab!e fall in the mortality from acute perforation of peptic ulcer. In the first 106 operated cases (1938-40) there were 27 deaths ; in the last $106(1947-8)$ there were only four. The series was not arranged as a statistical study of new anaesthetics or antibiotics, and new methods were introduced as they became available. Table $\mathrm{X}$ shows the progressive and

TABLE X.-Effects of Antibiotics and Anaesthetics (Excluding Local and Spinal)

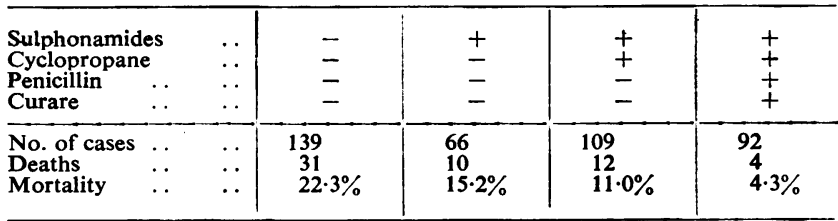

significant fall in mortality with the use first of sulphonamides, then of cyclopropane, and, finally, of penicillin and curare. Unfortunately, the total numbers are not large enough to determine whether the reduction was significant at each stage, but there is no doubt about the significant fall over the whole period.

It is probable that the antibiotics have played a larger part than the new anaesthetic techniques, for subphrenic abscess and purulent chest and wound infections have all shown a substantial decline in frequency and mortality. Better anaesthesia may well have contributed to the disappearance of the early deaths after perforation, as the toxic effects of heavy anaesthesia can now be avoided. The better relaxation achieved means less trauma to peritoneal structures, and this may reduce the frequency of abdominal complications. However, antibiotics have certainly cut short the post-operative peritonitis which formerly took its toll of early deaths.

Two further points suggesting the superior role of antibiotics are that spinal analgesia did not appreciably lower the operative mortality before the introduction of chemotherapy, and that at Hillingdon Hospital, a hospital similar to the Central Middlesex, during the past three years there have been 16 deaths among 116 operated cases. Curare was used extensively, but penicillin and sulphonamides were not given as a routine. The corresponding figures at this hospital, where there was a routine use of antibiotics, are seven deaths in 152 cases. To establish firmly the 
relative parts played by antibiotics and better anaesthesia would probably need a survey of cases from many hospitals, but the point is mainly academic.

An acute perforation is a major crisis for the body, and it is entirely reasonable to bring the best possib'e help to counter infection; routine penicillin and sulphonamides provide complementary assistance against Gram-positive and Gram-negative bacteria. It is noteworthy that the mortality has declined most in the duodenal ulcer group (Table XI). The early deaths have disappeared from both

TABLE XI

\begin{tabular}{|c|c|c|c|c|}
\hline & \multicolumn{2}{|c|}{ Gastric } & \multicolumn{2}{|c|}{ Duodenal } \\
\hline & $1938-42$ & $1943-8$ & $1938-42$ & $1943-8$ \\
\hline $\begin{array}{l}\text { Total No. } \\
\text { Deaths within first week } \\
\text { Later deaths .. }\end{array}$ & $\begin{array}{r}47 \\
9 \\
8\end{array}$ & $\begin{array}{l}53 \\
0(10) \\
9(9)\end{array}$ & $\begin{array}{r}129 \\
17 \\
11\end{array}$ & $\begin{array}{l}219 \\
4(29) \\
6(19)\end{array}$ \\
\hline
\end{tabular}

Expected deaths in parentheses, calculated on 1938-42 rate.

the gastric and the duodenal ulcer groups, but, although the deaths after the first week have greatly diminished in the latter, there is no corresponding fall in late deaths from gastric ulcer.

It is clear from the charts that associated haemorrhage has contributed particularly to this high delayed mortality and raises the advisability of emergency partial gastrectomy in selected cases of acute perforated chronic gastric ulcer. The problems of associated haemorrhage and perforation are being considered in a further paper.

The particular interest in post-operative care, apart from the use of antibiotics, has probably increased the comfort of the patient rather than had any real effect on the mortality. The administration of adequate amounts of fluids, avoiding any excess of salt, prevents the discomfort of dehydration and the dangers of hydraemia. Particular attention to the chest and stimulation of coughing and expectoration probably reduce the incidence of massive collapse of the lungs.

It may be thought that the fall in operative mortality must to some extent be due to the higher proportion of nonoperated cases in the later years. If this were associated with a change in attitude by the surgeon towards the desperately ill it. would indeed be an important factor. However, as previously stated, this is not so, and the increase of non-operated cases is due to improved diagnosis in the moribund group and to an increase in admissions among the oldest age groups.

Except in three extremely ill and complicated cases, no attempt has been made to assess the value of the medical management of acute perforation, but the present figures suggest that emergency operation, and therefore the elimination of faulty diagnoses, will remain the treatment of choice. Hermon Taylor (1946) reported 28 cases treated conservatively, with four deaths; and Visick (1946) had 14 cases, with three deaths. The combined series is small, but the results do not suggest that conservative treatment will equal modern surgical practice.

It should be pointed out, however, that Hermon Taylor did not give sulphonamides or penicillin, and that Visick used only sulphonamides. Perhaps the full assessment of medical management must await an unselected series in which full use is made of modern antibiotics. Medical management will certainly always play its part in those cases in which operation is virtually excluded by the severity of associated complications and in those which perforate when surgical assistance is unobtainable.
In previous series the increase in mortality with the increase in length of time between perforation and operation has often been recorded. It was noted in this series that this was true only for duodenal ulcer (Table XII).

TABLE XII.-Showing Lapse of Time Between Perforation and Operation

\begin{tabular}{|c|c|c|c|c|c|c|c|}
\hline & Hours: & $0-3$ & $3-6$ & $6-12$ & $12-18$ & $18-24$ & Over 24 \\
\hline $\begin{array}{c}\text { Gastric } \\
\text { ulcer } \\
\text { Duo- } \\
\text { denal } \\
\text { ulcer }\end{array}$ & $\begin{array}{ll}\text { No. } & \cdots \\
\text { Deaths } & \ddot{\%} \\
\text { Mortality } & \% \\
\text { No. } & \text { O. } \\
\text { Beaths } & \% \\
\text { Mortality } & \%\end{array}$ & $\begin{array}{l}9 \\
6 \\
66 \cdot 7 \\
48 \\
2 \\
4 \cdot 2\end{array}$ & $\begin{array}{c}37 \\
8 \\
21 \cdot 6 \\
160 \\
8 \\
5 \cdot 0\end{array}$ & $\begin{array}{l}33 \\
7 \\
21 \cdot 2 \\
91 \\
9 \\
9 \cdot 9\end{array}$ & $\begin{array}{l}11 \\
2 \\
18 \cdot 2 \\
19 \\
6 \\
31 \cdot 6\end{array}$ & $\begin{array}{c}7 \\
2 \\
28 \cdot 6 \\
13 \\
6 \\
46 \cdot 1\end{array}$ & $\begin{array}{c}2 \\
1 \\
50 \\
13 \\
7 \\
53 \cdot 8\end{array}$ \\
\hline
\end{tabular}

It is probable that acute perforations account for between 40 and $50 \%$ of the deaths from peptic ulcer, which in England and Wales are of the order of 5,000 a year. Halving the mortality from acute perforation would represent a reduction of at least a thousand deaths a year. Inquiry has shown that in some hospitals antibiotics are not given as a routine after operation.

\section{Management of Cases}

During the war years one of the three senior surgeons was always resident, and since the war an experienced senior assistant has been on duty within the hospital. A senior anaesthetist has always been quickly available. From 1940 practically all cases have been seen by one of us (F. A. J.), and the majority have been sent from the theatre to the medical dietetic wards, where the responsibility for post-operative care has been undertaken by the medical firm. On return from the theatre the patients are placed in a semi-reclining position but without knee pillows.

The fluid intake has been maintained at a minimum of 6 pints (3.4 litres) daily by giving continuous rectal fluid, using a rubber catheter (size 12 Jacques) connected by tubing with a drip connector and screw clip to a douchecan. Patients are very rarely intolerant of rectal administration of fluids given in this way, and with most there is no discomfort. It is an extremely simple and satisfactory technique. The accompanying schedule is used.

\begin{tabular}{|c|c|c|c|c|}
\hline & \multicolumn{4}{|c|}{ 24-hour Periods } \\
\hline & $1 \mathrm{st}$ & 2nd & 3rd & 4th \\
\hline $\begin{array}{l}\text { By mouth .. } \\
\text { Per rectum .. }\end{array}$ & $\begin{array}{c}1 \text { oz. }(28 \mathrm{ml} .) \\
\text { hourly } \\
6 \text { pints } \\
(3 \cdot 4 \text { litres })\end{array}$ & $\begin{array}{c}3 \text { oz. ( }(85 \mathrm{ml} .) \\
\text { hourly } \\
4 \text { pints } \\
(2 \cdot 3 \text { litres })\end{array}$ & $\begin{array}{c}5 \text { oz. }(140 \mathrm{ml} .) \\
2 \text {-hourly } \\
3 \text { pints } \\
(1 \cdot 7 \text { litres })\end{array}$ & $\begin{array}{l}\text { Light diet } \\
\text { 2-hourly }\end{array}$ \\
\hline
\end{tabular}

Dilute saline was given (one part normal saline to four parts of tap-water). This avoids an excess of salt, which causes hydraemia and oedema. If, however, there is postoperative vomiting or if gastric fluid is removed by aspiration the equivalent volume of normal saline is given intravenously to cover the lost fluid. This enables the electrolyte balance to be preserved and any gross excess of sodium chloride is avoided. A Ryle's tube is kept in the stomach for the first 24 hours, and longer if there should be any accumulation of gastric contents.

Penicillin, 200,000 units, is given pre-operatively and 100,000 units six-hourly intramuscularly for three days. Sulphadimidine is given by mouth as crushed tablets, $4 \mathrm{~g}$. on return to the ward and $2 \mathrm{~g}$. six-hourly for three days.

Particular attention has been paid to the chest, and the ward sister has made it her responsibility to ensure deep breathing and the coughing-up of sputum at four-hourly 
intervals throughout the day; the patient is also encouraged by firm pressure on the chest. If pain is too severe a preliminary injection of pethidine, $100 \mathrm{mg}$., is given.

Should there be any evidence of circulatory failure a rapid transfusion of intravenous saline is given, with, if necessary, plasma. Apart from cases with associated haemorrhage, it has rarely been necessary to transfuse with blood.

At operation, simple suture has been undertaken and usually omentum is brought over the ulcer. Particular care is taken to swab above the liver for residual fluid.

Post-operative pain is alleviated by morphine $1 / 6 \mathrm{gr}$. (11 mg.) at night, and pethidine, $100 \mathrm{mg}$., intramuscularly by day, for the first two or three days. An enema is given on the third morning. The patient is allowed up on the fourth day and the sutures are removed on the tenth day. If any evidence of venous thrombosis is discovered anticoagulant therapy as described by Ball and Hughes (1949) is started.

\section{Summary}

An analysis is presented of 490 cases of acute perforation treated from 1938 to 1948 , inclusive.

The total mortality and the operative mortality have fallen considerably.

During the first three years the operative mortality was $27 \%$; during the last two years it was only $4 \%$. It was thought that this improvement is mainly due to better anaesthesia and to the routine use of antibiotics.

A summary of routine management of cases is presented.

We wish to express our thanks to the surgeons who have allowed us to treat these cases post-operatively: Mr. T. G. I. James, Mr. J. D. Fergusson, Mr. N. M. Matheson, Mr. J. Bonnin, and Mr. C. Chapple. We are also most grateful to the anaesthetists, Dr. Rankin, Dr. Davenport Jones, Miss McClelland, and Miss Ransom, and to the ward sisters who have given us such great assistance; we should like to mention particularly Sister Edmunds and Sister Johnstone. We wish to thank Mr. Duncan, of Hillingdon Hospital, who kindly supplied the figures from his hospital, and to Mr. J. Wilson for help in tracing the earlier cases.

\section{REFERENCES}

Ball, K. P., and Hughes, H. O. (1949). British Medical Journal, 1, 560.

Baritell, A. L. (1947). Surgery, 21, 24.

DeBakey, M (1940). Ibid., 8, 1028.

Doll, R. (1950). British Medical Journal, 1, 215.

Graham, R. R., and Tovee, E. B. (1945).' Surgery, 17, 704.

Houston, W. (1946). British Medical Journal, 2, 221.

Illingworth, C. F. W., Scott, L. D. W., and Jamieson, R. A. (1944). Ibid., 2, 617, 655 .

Johansson, O. (1947). Acta chir. scand., 95, 233.

McClure, R. D. (1940). In Frank Howard Lahey Birthday Volume, p. 321. Springfield, Illinois.

McElhinney, W. T., and Hozzer, C. E. (1948). Surg. Gynec. Obstet., 87, 85 .

Sangster, A. H. (1948). Lancet, 2, 289.

Taylor, H. (1946). Ibid., 2, 441 .

Visick, A. H. (1946). British Medical Journal, 2, 941.

A study of the arrangements for the care of children under school age is being made by Miss Gladys Pendred, Federal Officer of the Australian Association for Pre-school Child Development, during a two months' visit to the United Kingdom under the auspices of the British Council. Her programme includes visits to nursery schools, organizations dealing with research and guidance, teachers' training colleges, and central and local government departments. She arrived in Britain on January 7 and spent the first three weeks in London. Later she will probably visit Scotland for two weeks and Durham for a few days. Trained as a teacher, Miss Pendred became Director of Free Kindergartens in Melbourne in 1925, was Principal of the Kindergarten Training College, Perth, from 1928 to 1937, and Supervisor of the Kindergarten Union of Western Australia from 1940 to 1941.

\section{PERFORATED CARCINOMA OF THE STOMACH SIMULATING PERFORATED GASTRIC ULCER}

BY

RICHARD DOLL, M.D., M.R.C.P.

Member of the Staff of the Statistical Research Unit, Medical Research Council

(From the Gastro-enterological Department, Central Middlesex Hospital)

Occasional instances of perforation complicating carcinoma of the stomach have been reported for many years, but only recently has the condition been recognized to be common. Aird (1935) could find only 71 cases in the literature, to which he added seven cases from the records of the Edinburgh Royal Infirmary and one personal case. Since then several large series have been reported, including 36 by Boyce (1946), 44 by Bocharov (1944), and 133 by McNealy and Hedin (1938).

According to Bisgard and Overmiller (1944), perforation occurs in from 3 to $6 \%$ of all cases of gastric carcinoma admitted to hospital, the average incidence being $4 \%$. In about half the cases the signs and symptoms are obscure and many have not been recognized until after death. The other half clinically resemble perforated peptic ulcers and are of particular interest, as they are often early cases and eminently suitable for radical surgery.

At the Central Middlesex Hospital, in the eleven years 1938-48, there have been 17 instances of perforated carcinoma of the stomach. Perforations were found at operation 11 times, but only three were recognized to be carcinomatous. A fourth was diagnosed as carcinoma by gastroscopy shortly afterwards, but seven were discharged from hospital with the diagnosis of simple gastric ulcer. Contrary to belief, perforation in a carcinoma does not result in the early development of peritoneal secondaries, and failure to make the diagnosis must be considered particularly unfortunate, as it is likely to occur when the lesion is local and when resection may offer a reasonable prognosis. The object of this paper is to draw attention to the frequency with which perforation occurs in carcinoma of the stomach and to suggest how the risk of misdiagnosis may be reduced.

Brief details of the 17 cases are shown in Table I. Fuller histories of the misdiagnosed cases are appended.

In some of the first seven cases it can be argued that the lesion was a simple ulcer at the time of perforation and that carcinoma developed subsequently in the ulcer or independently elsewhere in the stomach. The latter would seem unlikely because of the close relation between the site of the perforation and of the carcinoma when diagnosed. The former is a possibility in Cases 4,5 , and 6 , in which the intervals between perforation and definite evidence of a neoplasm were 26,30 , and 22 months respectively, but in the others the intervals were short, being in each case less than one year. Two and a half years, however, is not a long history for carcinoma of the stomach, and it is more reasonable to believe that the perforation was related to the carcinoma in all.

During the same period, $1938-48$, a total of 452 patients with perforation of the stomach and duodenum were operated on, 449* of which were thought to be benign

*The 455 perforations operated on, reported by Avery Jones, Parsons and White (1950), included seven cases of jejunal ulcers and excluded Case 8 above, which was recognized to be carcinomatous before discharge from hospital. 